\title{
腹腔鏡下手術にて摘出した後腹膜リンパ管腫の 1 例
}

\author{
富山労災病院外科 \\ 小林弘信道輪良男江嵐充治松木伸夫
}

腹腔鏡下手術にて摘出した後腹膜リンパ管腫の 1 例を経験した. 症例は 44 歳, 女性. 自覚症状は特になく, 乳癌手術の術前腹部 $\mathrm{CT}$ 検査で膵近傍の襄腫状腫瘤を指摘され, 9 力月後の検査で増大傾向を認めたため手術目的に入院となった. 精查の結果, 膵体部 頭側の後腹膜腔に発育した襄胞性疾患と診断し，本邦では 2 例目となる腹腔鏡下手術を 行った. 手技上の問題点は特になく, 䟝離は容易であった。病理組織学的には䧶胞状り ンパ管腫であった. 術後10カ月目のCT 検査でも再発は認めなかった.

索引用語 : 後腹膜りンパ管腫, 腹腔鏡下摘出術

\section{緒 言}

近年, 腹腔鏡下手術が胆哓摘出術における minimally invasive surgery として市民権を得るや, 種々の疾 患に対する手術へ応用が拡大されてきている1). 今回, われわれは比較的稀とされる後腹膜リンパ管腫(以下, 本症）に対して本邦第 2 例目となる腹腔鏡下手術を行 ったので，若干の文献的考察を加え報告する。

$$
\text { 症例 }
$$

患者：44歳, 女性.

主訴：特になし。

家族歴：特になし.

既往歴：8 歳, 虫垂切除術, 43歳, 定型的乳房切断 術.

現病歴：1998年 1 月, 他院で乳癌の手術施行. その 際の術前腹部 CT 検查で膵近傍の哓腫状腫瘤を指摘さ れた. 夫の転勤で 4 月より当科で経過観察となり， 9 月の CT で増大傾向を認め手術目的に入院となった.

入院時現症：身長 $156 \mathrm{~cm}$, 体重 $52.5 \mathrm{~kg}$. 血圧 $126 / 70$ $\mathrm{mmHg}$. 負血, 黄㾝なく, 表在リンパ節は触知しなか つた.腹部は右下腹部に手術創を認めるのみであった。

入院時検査成績：一般血液検查に異常なく, 腫煌 ーカー (CEA, CA19-9) も正常範囲内であった.

腹部超音波検査：膵体部の頭側に位置する径 $5 \mathrm{~cm}$ 大の単胞性䧶腫状病変を認めた (図 1 ).

腹部 CT 検查：病変は境界明瞭であり, 内部は均一 な低吸収域で, enhanceされなかった（図 2 ）。

1999年11月 22 日受付 2000 年 5 月 8 日採用
腹部 MRI 検査：T1 強調画像では低信号域， $\mathrm{T} 2$ 強 調画像では高信号域を呈した（図 3 ).

胃十二指腸造影検查：胃体部小弯に外方からの圧排 所見を認めた。

ERP 検査：特に異常を認めなかった。

腹部血管造影検查：動脈系に異常を認めないものの

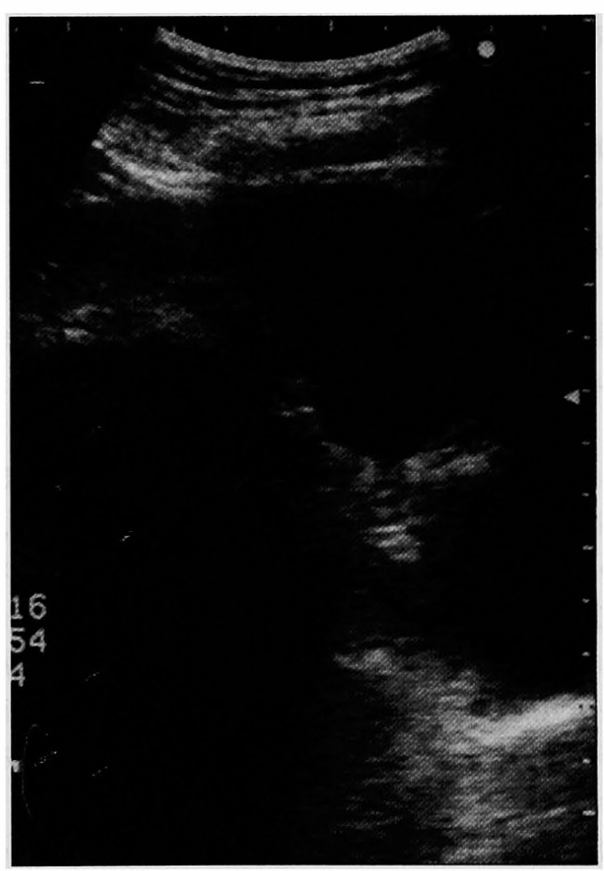

图 1 腹部超音波検査：膵体尾部の頭側に径 5 $\mathrm{cm}$ 大の単胞性僿腫状病変を認めた。 

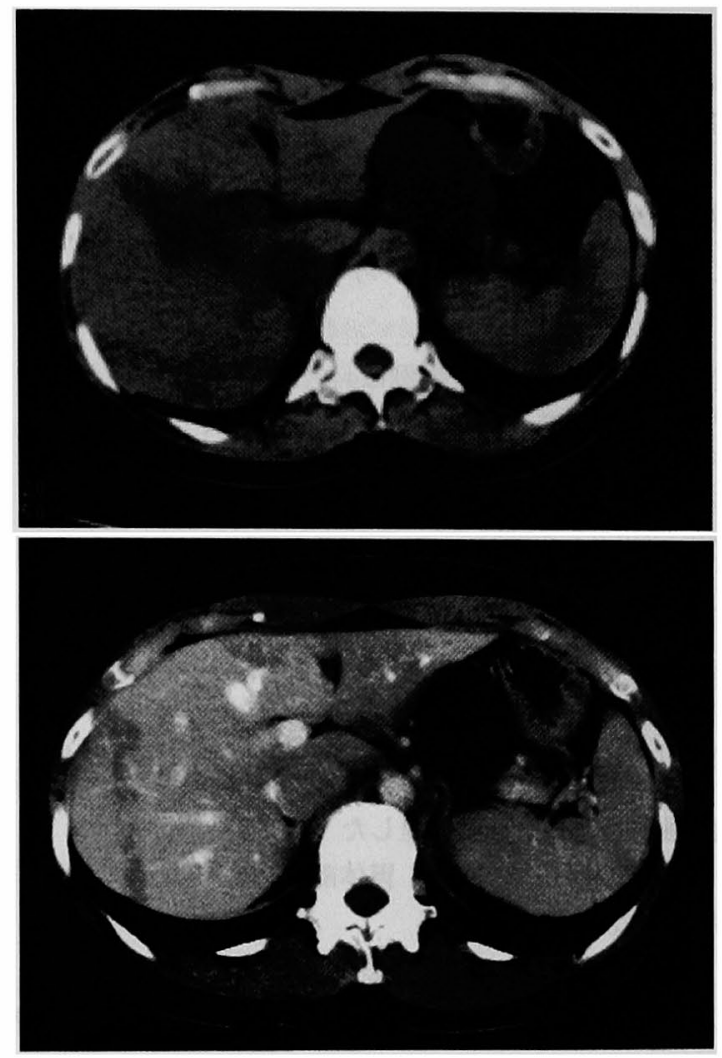

図 2 腹部 CT 検査：病変は境界明瞭, 内部は均一な低吸 収域で, enhanceされなかった。

脾静脈に上方からの軽度圧排所見を認めた。

以上の所見から, 膵体部頭側の後腹膜腔に発育した 襄胞性疾患と診断し，10月 6 日十分なインフォーム ド・コンセントをえて腹腔鏡下手術を行った。

手術所見：小切開法にて臍部より $5 \mathrm{~mm}$ 腹腔鏡を挿 入し，剣状突起下右側，左季肋部鎖骨中線上にそれぞ れ $5 \mathrm{~mm}$, 臍左側前腋窩線上に $10 \mathrm{~mm}$ トロッカーを穿 刺し操作孔として気腹法にて行った，腫場は約 $5 \mathrm{~cm}$ 大, 半球状で小網越しに後腹膜腔内に確認された. 胼 との癒着は軽度であった，後腹膜および一部の索状物 は電気メスや Harmonic Scalpel (LCS) を用いて切離 したものの，殆ど鉗子や玉ッッペルを用いた剝離操作

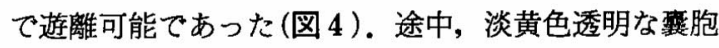
内容の流出を認めたが殆どを吸引回収しえた，手術時 間は130分，出血量は少量であった。

病理組織学的所見：襄胞壁は内腔をおおう一層の扁 平な内皮細胞とその外側の平滑筋線維束よりなり, 組 織学的診断は亨胞状リンパ管腫であった。
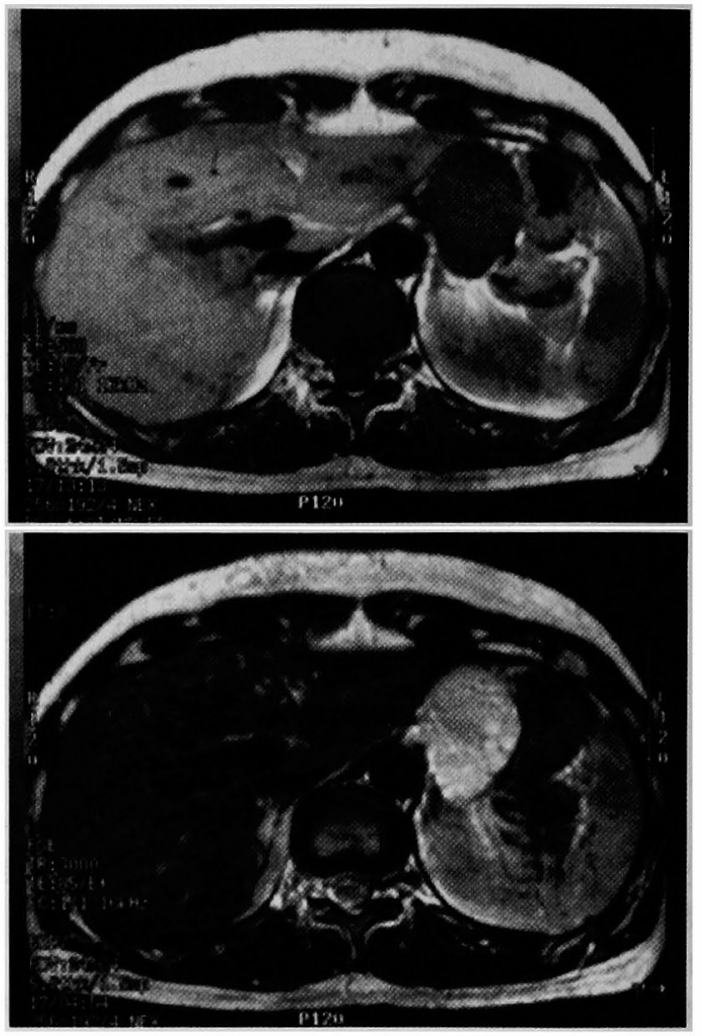

图 3 腹部 MRI 検查: T1 強調画像では低信号域, T2 強調画像では高信号域を呈した.

術後経過：経過良好で術後 4 日目に退院した. 術後 10力月目の CTでも再発は認めていない.

\section{考 察}

リンパ管腫は小児の頸部や腋简などの体表に多い疾 患である ${ }^{2)}$. 成因は現在のところ胎生異常説が有力で あり，䧶腫の増大は一般にかなり緩徐である3).したが って, 本症は発生部位が後腹膜という深在性であるた め, 感染や出血による腹痛. その他の炎症症状を合併 しない限り，他臟器圧排症状あるいは腫瘤触知などの 症状が現れにくく稀とされる。

本邦では1913年に初めて飯田出が報告して以来, 1998年小松ら5の集計でも126例の報告のみである.し かし, 各種画像診断法の進歩により偶然発見される機 会も多く報告数は年々増加傾向にある ${ }^{3)}$. 自験例でも 乳癌の術前検查にてはじめて発見された。

本症の治療は外科的切除が第一選択であり, 颔腫の 不完全切除では再発が問題となることから全摘が理想 的である6).なお，無症状で腫瘤も小さく画像などで確 

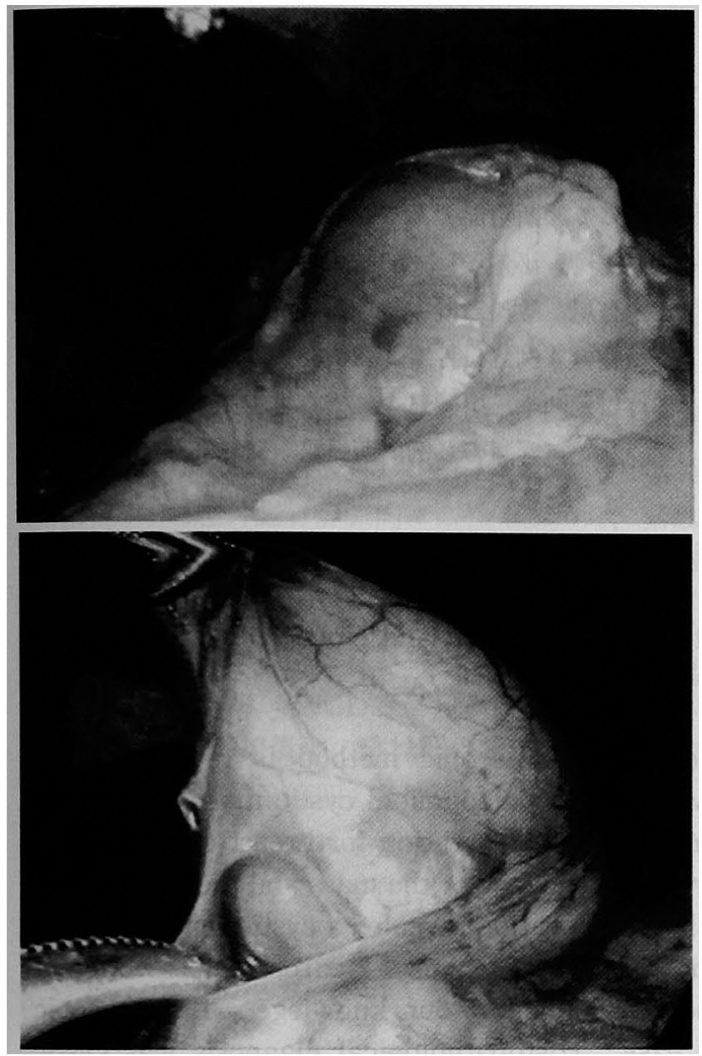

图 4 手術所見: 腫瘍は約 $5 \mathrm{~cm}$ 大, 半球状で後腹膜腔 内に確認された．殆ど釹子などを用いた㔀離操作にて 遊離可能であった。

診がえられれば経過観察でもよいという意見もある゙ が，その場合，外傷性機転にて急激に発症する7)可能性 についての十分な説明が必須である．自験例も無症状 で，腫瘤径の増大を認めたものの未だ小さく，手術時 期は最終的には患者と相談の上決定した。

手術方法としては,これまで通常の開腹術が施行さ れてきた。しかし，腹腔鏡下手術が胆㖶摘出術におけ る minimally invasive surgeryとして市民権を得る や，種々の疾患に対する手術へ応用が拡大されてきて いる現状の中 ${ }^{1)}, 1997$ 年村上ら ${ }^{8)}$ は本邦で初めて本症に 対して施行した，本症が通常良性疾患であることや沢 井ら》の集計では全摘術が施行された症例のほとんど が容易に摘除されていることより，本症もよい適応と 思われる。しかし, 周囲蔵器を巻き込み, これら㵴器 の合併切除が余儀なく行われた症例も比較的高頻度で あり"，これら症例では通常の開腹術でも難易である ことから症例の選択は慎重に行う必要がある．当科で
も十分なインフォームド・コンセントをえて腹腔鏡下 手術を試みた．本邦では第 2 例目となる．自験例での 手技上の問題点はとくになく，别離が想像以上に容易 であったことを実感した。炎症所見がなかったことに 加え, 腫瘤径も $5 \mathrm{~cm}$ と小さかったためと思われた。

本症は組織形態では単純性. 海綿状, 萁胞状に分類 され，陆胞状が約 $90 \%$ を占める ${ }^{10}$. 腫場性格と摘出可能 との関係では，山口ら ${ }^{11}$ は海綿状は頻度は少ないが浸 潤性に発育する傾向にあり，合併切除や全摘不能例が 多かったと述べている.また, Raszkowski らは海綿状 あるいは多房性リンパ管腫では周囲に浸潤して発育す ることが特徵で摘出困難例が多かったと報告してい る ${ }^{12}$. さらに, 海綿状では悪性化の報告 ${ }^{6}$ も認め, 海綿 状リンパ管腫においては臨床上慎重な対処が必要と思 われた.したがって，腹腔鏡下手術の適応を論じる上 で，現時点では海綿状リンパ管腫を除外するほうが妥 当と思われた.この点て，岩元ら ${ }^{13}$ は画像所見と組織型 の関係に言及し，䒼胞状と海綿状との区別を試みてい る.しかしながら, 組織学的には相互に移行型もみら れる代ことから画一的なものではない．自験例での術 前診断では海綿状リンパ管腫は否定的であった。

\section{結語}

腹腔鏡下手術にて切除しえた後腹膜リンパ管腫の 1 例を報告するとともに腹腔鏡下手術の適応についても 言及した。

\section{文献}

1）大上正裕，渡邊昌彦，大谷吉秀他：特集腹腔鏡下 手術 最新のテクニック. 胃・大腸早期癌に対する 腹腔鏡下手術の pitfall 並びに手術操作の要点. 手 術 $49: 609-615,1995$

2）田代和弘，吉田晃治，野中道泰 他：後腹膜原発霹 胞性リンパ管腫の 1 症例. 外科診療 $31: 758-$ 763,1989

3）落合正宏，内村正史，村岡正朗他：急性虫垂炎様 症状で発症した後腹膜㥲腫状リンパ管腫の 2 例一 最近10年間の報告例を中心とした文献的考察一． 日臨外医会誌 $57 ： 1226-1230 ， 1996$

4）飯田庄八：腹膜後部碓腫の 1 例. 日外会誌 14 ： 277-286, 1913

5）小松永二，石塚直樹，濱谷弘康他：急性腹症を呈 した後腹膜萁胞性リンパ管腫の 1 例. 日臨外会誌 $59: 3176-3179,1998$

6）黑川善栄，神谷順一，桐岡智二他：脾頭十二指腸 切除術にて切除しえた後腹膜リンパ管腫の 1 例. 
日外会誌 $88: 222-226,1987$

7）佐野克行，川崎千最, 佐藤和彦他：乳糜を内容と した後腹膜の海編状リンパ管腫の 1 例. 泌紀 $36: 1435-1438,1990$

8）村上真基, 林 留, 宗像康博：後腹膜海綿状リ ンパ管腫に対する腹腔鏡下切除術。日消外会誌 $30: 376,1997$

9）沢井博純，中村 司，林 周作他：成人後腹膜リ ンパ管腫の 1 例. 日臨外医会誌 $56 ： 2215-2219$, 1995
10）森本泰介，粟津篤司，田代久夫他：後腹膜原発焦 状リンパ管腫の 1 例と本邦報告例の検討. 日臨外 医会誌 $44 ： 912-918,1983$

11）山口千美，冨田京一，金子裕憲他：リンパ管造影 にて診断可能であった後腹膜豊腫状リンパ管隀の 1 例。泌外 $1: 363-368 ， 1988$

12）有馬 敬, 三輪 勝, 高井清一他: 後腹膜淋巴管 腫の 4 例. 日外宝 $42: 381-390,1973$

13）岩元則幸，川瀨義夫，橋本哲也他：後腹膜原発の リンパ管腫の 2 例. 西日泌 $51: 561-565,1989$

\title{
A CASE OF RETROPERITONEAL LYMPHANGIOMA RESECTED BY LAPAROSCOPIC METHOD
}

\author{
Hironobu KOBAYASHI, Yoshio MICHIWA, Mitsuharu EARASHI and Nobuo MATSUKI \\ Department of Surgery, Toyama Rousai Hospital
}

A case of retroperitoneal lymphangioma resected by laparoscopic method is reported. An asymptomatic 44-year-old woman was pointed out having an intra-abdominal cystic mass adjacent to the pancreas by abdominal CT scan which was performed prior to operation for breast cancer. Nine months later, another abdominal CT scan revealed a growing tendency of the mass and the patient was admitted to the hospital for the purpose of operation. Close exploration revealed a cystic tumor existing in the retroperitoneal cavity of the cranial site to the body of pancreas. And a laparoscopic resection of the tumor was carried out. This is the second report in Japan to our knowlege. Laparoscopic management was satisfactory and abration was very easy. Histopathological diagnosis was cystic lymphangioma. There has been no signs of recurrence as of ten months after the operation. 